\title{
EFFECT OF DECIDUAL CELL-INDUCING STIMULI ON THE PASSAGE OF SODIUM INTO THE UTERINE LUMEN OF THE RAT
}

\author{
P. B. MARLEY* AND J. M. ROBSON $\dagger$ \\ Department of Pharmacology, Guy's Hospital Medical School, London, S.E.1
}

(Received 11th February 1971, accepted 27th May 1971)

Summary. The rate of passage of intravenously injected $\left[{ }^{2} \mathrm{Na}\right]$ sodium
into the perfused uterine lumen of the rat was measured in vivo on the
day after the application of decidual cell-inducing stimuli, i.e. the injec-
tion of arachis oil or the insertion of a thread into the uterine lumen.
The oil injection induced a decidual cell reaction and decreased the
rate of passage of ${ }^{22} \mathrm{Na}$ by some $50 \%$ when injected on Day 5 of pseudo-
pregnancy. By contrast, it produced neither of these effects when in-
jected at metoestrus, suggesting that the decrease in rate is associated
with decidual cell formation.
The presence of a thread in the uterine lumen for 1 day increased the
rate markedly both in horns threaded on Day 5 of pseudopregnancy
and at metoestrus. When the thread was present for longer periods, the
rate declined and the uterus became unresponsive to further threading.

\section{INTRODUGTION}

The rate of passage of intravenously injected ${ }^{22} \mathrm{Na}$ into the perfused uterine lumen has been measured in vivo in the rat and was shown to vary significantly at different stages of the oestrous cycle and during the first 10 days of pregnancy and pseudopregnancy (Marley \& Robson, 1971). Some of the variations appeared to be due to changes in the levels of circulating oestrogen and progesterone and others to changes brought about by the process of implantation and the growth of the implantation site. In the present work, we have investigated the extent to which the changes associated with implantation are due to the growth of decidual cells. Two decidual cell-inducing stimuli were used, i.e. injection of arachis oil and insertion of a thread into the lumen, at various stages of the reproductive cycle. The oil stimulus is considered mild and produces a discrete growth similar to implantation sites (Finn \& Keen, 1962). The insertion of a thread into the lumen (Long \& Evans, 1922) is a stronger stimulus and produces decidual cell formation throughout the uterine endometrium. At other stages, it also has the property of inhibiting decidual cell formation and nidation (Doyle \& Margolis, 1963; Margolis \& Doyle, 1964; Marston \& Chang, 1964).

* Present address: Department of Pharmacology, The School of Pharmacy, University of London.

$\dagger$ Present address: Department of Pharmacology, Chelsea College of Science and Technology, University of London. 


\section{METHODS}

Albino Wistar rats bred in the Animal House of Guy's Hospital Medical School which had had three 4-day oestrous cycles consecutively were used. The rats were nulliparous and weighed between 200 and $300 \mathrm{~g}$. Pseudopregnancy was induced by mating with vasectomized males implanted with testosterone, and the day of mating was called Day 1. Decidual cell-inducing stimuli were given under ether anaesthesia and the perfusions were performed under pentobarbitone sodium anaesthesia $(25 \mathrm{mg} / \mathrm{kg}$ intraperitoneally).

Two methods were used to induce a decidual cell reaction. In the first (Finn \& Keen, 1962), $0.05 \mathrm{ml}$ arachis oil was injected unilaterally into the uterine lumen at the uterotubal junction at midday on Day 5 of pseudopregnancy, or at metoestrus. In the second method, a thread was placed unilaterally along the entire length of the lumen (Long \& Evans, 1922). A 3-in. long straight needle, sterilized after threading with a length of 3-0 gauge silk thread, was worked along the lumen, inserting it at the cervical end and withdrawing it at the ovarian end. The ends of the thread were knotted $0.5 \mathrm{~cm}$ from where they emerged to keep them in place.

The details of the perfusion technique have been described elsewhere (Marley \& Robson, 1971).

An intravenous injection of 4 to $10 \mu \mathrm{Ci}^{22} \mathrm{Na}$ was given into a tail vein $25 \mathrm{~min}$ before the start of the perfusion, to allow the ${ }^{22} \mathrm{Na}$ to become distributed and its concentration in the blood to become constant. The perfusate collected during the first $5 \mathrm{~min}$ of the perfusion was discarded. The perfusate collected 30 to $60 \mathrm{~min}$ after the injection was used to determine the rate of passage of

${ }^{2} \mathrm{Na}$ into the uterine lumen. The total radioactivity present in the perfusate was expressed as a percentage of the radioactivity in an arbitrary volume of $1 \mathrm{ml}$ of plasma, a blood sample being taken at the end of the perfusion.

\section{Oil stimulus}

\section{RESULTS}

On Day 6 of pseudopregnancy, the ${ }^{22} \mathrm{Na}$ content of the perfusate from the horns injected with arachis oil was about $50 \%$ less than that from the control horns. The horns injected with oil were heavier than the controls and histological examination confirmed that the oil had induced a decidual cell reaction in all six (Table 1).

In rats in which the oil was injected at metoestrus with perfusion the following day, there was no difference respectively in either the ${ }^{22} \mathrm{Na}$ content of the perfusate or the uterine weight (Table 1) between the horns injected with oil and the controls.

\section{Thread stimulus}

The ${ }^{22} \mathrm{Na}$ content of the perfusate from threaded horns was greater than that from control horns both on Day 6 of pseudopregnancy and at dioestrus, the thread having been in place for one day. Only on Day 6 of pseudopregnancy, however, was the uterus significantly heavier, due to decidual cell growth (Table 1). 
In two instances where the thread was removed immediately after its insertion (sham threading), the ${ }^{22} \mathrm{Na}$ content of the perfusate was similar to that from the control horns on the following day (Table 1).

In rats in which the thread was inserted at metoestrus and perfusion was performed three cycles and a day later at dioestrus, the ${ }^{22} \mathrm{Na}$ content of the perfusates from the threaded horns was much less than that found 1 day after threading. This suggests that the increased rate of passage of ${ }^{22} \mathrm{Na}$ into the lumen gradually decreases with time (Table 1 ).

TABLE 1

THE EFFECTS OF UNILATERAL INJEGTION OF ARAGHIS OIL OR THREAD INSERTION, INTO THE UTERINE LUMEN, ON THE RATE OF PASSAGE OF [ ${ }^{22} \mathrm{Na}$ ] SODIUM INTO THE PERFUSED UTERINE LUMEN AND ON THE UTERINE WEIGHT IN RATS

\begin{tabular}{|c|c|c|c|c|}
\hline \multicolumn{2}{|l|}{ Stage and treatment } & $\begin{array}{l}\text { No. of } \\
\text { horns } \\
\text { perfused }\end{array}$ & $\begin{array}{l}{ }^{22} \mathcal{N} a \text { content } \\
\text { of perfusate } \\
\text { Mean } \pm S . E .\end{array}$ & $\begin{array}{c}\text { Uterine } \\
\text { weight } \\
\text { (mg/horn) } \\
\text { Mean } \pm \text { S.E. }\end{array}$ \\
\hline $\begin{array}{l}\text { 1. Injected Day } 5 \text { of pseudo- } \\
\text { pregnancy, perfused Day } 6\end{array}$ & $\begin{array}{l}\text { Gontrol } \\
\text { Oil }\end{array}$ & $\begin{array}{l}6 \\
6\end{array}$ & $\begin{array}{l}9 \cdot 8 \pm 0 \cdot 6 \\
5 \cdot 0 \pm 0 \cdot 9 * * *\end{array}$ & $\begin{array}{l}213 \pm 26 \\
393 \pm 24^{* * *}\end{array}$ \\
\hline $\begin{array}{l}\text { 2. Injected at metoestrus, } \\
\text { perfused } 1 \text { day later (dioestrus) }\end{array}$ & $\begin{array}{l}\text { Control } \\
\text { Oil }\end{array}$ & $\begin{array}{l}6 \\
6\end{array}$ & $\begin{array}{l}4 \cdot 0 \pm 0 \cdot 4 \\
4 \cdot 1 \pm 0 \cdot 5^{\mathrm{N} . \mathrm{s}}\end{array}$ & $\begin{array}{l}171 \pm 9 \\
171 \pm 8^{\text {N.s. }}\end{array}$ \\
\hline $\begin{array}{l}\text { 3. Threaded Day } 5 \text { of pseudo- } \\
\text { pregnancy, perfused Day } 6\end{array}$ & $\begin{array}{l}\text { Control } \\
\text { Sham } \\
\text { Thread }\end{array}$ & $\begin{array}{l}4 \\
1 \\
5\end{array}$ & $\begin{array}{l}12 \cdot 1 \pm 2 \cdot 9 \\
13 \cdot 7 \\
38 \cdot 3 \pm 1 \cdot 6^{* * *}\end{array}$ & $\begin{array}{l}217 \pm 33^{* *} \\
520 \\
415 \pm 41\end{array}$ \\
\hline $\begin{array}{l}\text { 4. Threaded at metoestrus } \\
\text { (i) Perfused 1 day later } \\
\text { (dioestrus) }\end{array}$ & $\begin{array}{l}\text { Control } \\
\text { Sham } \\
\text { Thread }\end{array}$ & $\begin{array}{l}2 \\
1 \\
3\end{array}$ & $\left.\begin{array}{l}\begin{array}{l}3 \cdot 3 \pm 1 \cdot 1 \\
4 \cdot 7\end{array} \\
43 \cdot 5 \pm 1 \cdot 3^{* * *}\end{array}\right\}$ & $\begin{array}{l}183 \pm 17 \\
238 \pm 35\end{array}$ \\
\hline 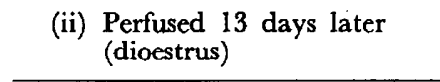 & $\begin{array}{l}\text { Control } \\
\text { Thread }\end{array}$ & $\begin{array}{l}4 \\
4\end{array}$ & $\begin{array}{l}4 \cdot 2 \pm 0 \cdot 8 \\
7 \cdot 1 \pm 2 \cdot 0 \\
\end{array}$ & $\begin{array}{l}187 \pm 27 \\
263 \pm 43\end{array}$ \\
\hline $\begin{array}{l}\text { 5. Threaded Days } 2 \text { and } 5 \text { of } \\
\text { pseudopregnancy, perfused } \\
\text { Day } 6\end{array}$ & $\begin{array}{l}\text { Control } \\
\text { Thread }\end{array}$ & $\begin{array}{l}5 \\
5\end{array}$ & $\begin{array}{c}8 \cdot 0 \pm 0 \cdot 9 \\
10 \cdot 3 \pm 1 \cdot 6^{\text {N.s. }}\end{array}$ & $\begin{array}{l}161 \pm 12 \\
316 \pm 50^{*}\end{array}$ \\
\hline
\end{tabular}

Contralateral horns served as controls. Sham refers to horns where the thread was removed immediately after its insertion.

Levels of significance, compared with contralateral horns: ${ }^{* * *} P<0.001 ;{ }^{* *} P<0.01$;

$* P<0.05$; N.S., not significant.

$\dagger$ Counts/min/30-min perfusate sample $\times 100$. Counts $/ \mathrm{min} / \mathrm{ml}$ plasma from same rat

When a thread was inserted into the uterine lumen on Day 2 of pseudopregnancy, and another inserted as before on Day 5 , the characteristic increase in ${ }^{22} \mathrm{Na}$ content of the perfusate on Day 6 did not occur (Table 1). The presence of a thread in the lumen for 3 days appeared to have made the uterus unresponsive. No decidual cells were formed but the threaded horns were heavier than the control horns on Day 6 (Table 1). A similar increase in weight was seen on Day 6 in horns threaded on Day 2 only (control, 188 \pm 16 , mean \pm S.E., threaded, $340 \pm 42, \mathrm{n}=6, P<0.01)$.

\section{DISCUSSION}

These experiments were performed primarily to find out whether the transitory 
decrease in the rate of passage of ${ }^{22} \mathrm{Na}$ into the uterine lumen occurring on the day of implantation, i.e. Day 6 (Marley \& Robson, 1971) is accounted for by some factor elaborated by the blastocyst, or is due to changes associated with decidual cell formation.

The results obtained with arachis oil as the stimulus support the concept that the rate of passage of sodium is reduced by changes associated with decidual cell formation. It is not known how this is brought about. When decidual cell formation is induced, the permeability of blood vessels increases and the endometrium becomes oedematous (Psychoyos, 1960; Lobel, Tic \& Shelesnyak, 1965). Subsequently, the oedema may lead to a decrease in blood flow, due to a higher resistance to flow, which would lower the rate of passage of ${ }^{22} \mathrm{Na}$ into the lumen. Another possibility is that the differentiation and rearrangement of stromal cells into decidual cells may alter the ability of sodium to diffuse across the endometrium into the lumen.

It would appear that the insertion of a thread into the uterine lumen produces complex effects other than decidual cell induction. The initial effect of threading was a marked increase in the rate of passage of ${ }^{22} \mathrm{Na}$ into the lumen. It is unlikely that this was due to damage at the time of threading since it did not occur if the thread was not retained in situ. Insertion of a thread into the uterine lumen evokes an inflammatory reaction (Parr, Schaedler \& Hirsch, 1967) and the initial consequences of this may explain the effects observed here. The inflammatory reaction had not progressed to oedema, however, since the uterine weight was not significantly greater in the threaded horns of dioestrous rats.

As far as the sodium permeability is concerned, the long term effect of threading appears to make the uterus unresponsive, either to the thread in situ or to additional threading. At this time, the threaded horns were heavier than the control horns, probably because of oedema resulting from the presence of a foreign body in the uterus (Parr \& Segal, 1966). If the rate of passage of ${ }^{22} \mathrm{Na}$ did not change with further threading because no new inflammatory response was induced, it would follow that implantation and decidual cell formation would not occur, since the first changes associated with these processes resemble those of an inflammatory reaction (Psychoyos, 1960). This could explain why a thread has to be in place for some days before it exerts its antifertility effect (Schuchner \& Davidson, 1964; Psychoyos \& Bitton, 1966).

\section{ACKNOWLEDGMENTS}

This work was in part supported by grants from the Population Council, New York and the Medical Research Council, whose help we gratefully acknowledge.

\section{REFERENCES}

Doyle, L. L. \& Margolis, A. J. (1963) Intrauterine foreign body: effect on pregnancy in the rat. Science, N.Y. 139, 833.

FinN, C. A. \& KeEN, P. M. (1962) Studies on deciduomata formation in the rat. F. Reprod. Fert. 4, 216.

Lobel, B. L., Tic, L. \& Shelesnyak, M. C. (1965) Studies on the mechanism of nidation. XVII. Histochemical analysis of decidualization in the rat. Part 2: Induction. Acta endocr., Copenh. 50, 469. 
Long, J. A. \& Evans, H. M. (1922) The oestrous cycle in the rat and its associated phenomena. Mem. Univ. Calif. 6, 1.

Margolis, A. J. \& Doyle, L. L. (1964) Intrauterine foreign body. II. Inhibition of decidual response in the rat. Fert. Steril. 15, 607.

Marley, P. B. \& Robson, J. M. (1971) Passage of sodium into the uterine lumen of the rat during the sexual cycle and under the influence of steroidal hormones. F. Reprod. Fert. 26, 287.

Marston, J. H. \& Chang, M. C. (1964) Action of intra-uterine foreign bodies in the rat and rabbit. In: Intrauterine Contraception. Proc. 2nd Int. Conf., p. 242. Eds. S. J. Segal, A. L. Southam and K. D. Schafer. Excerpta Med. Fdn, New York.

Parr, E. L., Schaedler, R. W. \& Hirsch, J. G. (1967) The relationship of polymorphonuclear leukocytes to infertility in uteri containing foreign bodies. F. exp. Med. 126, 523.

PARr, E. L. \& SEgAL, S. J. (1966) The effect of an intrauterine contraceptive device on the weight of the rat uterus. Fert. Steril. 17, 648.

Psychoyos, A. (1960) La réaction déciduale est précédée de modifications précoces de la perméabilité capillaire de l'utérus. C.r. Séanc. Soc. Biol. 154, 1384.

Psychoyos, A. \& Bitton, V. (1966) Aspects chronologiques de l'effet anti-implantatoire de la présence d'un fil dans l'utérus de la ratte. C.r. Séanc. Soc. Biol. 160, 229.

SChuchner, E. \& Davidson, O. W. (1964) The effect on rat pregnancy of an intra-uterine silk thread. In: Intra-uterine Contraception. Proc. 2nd Int. Conf., p. 248. Eds. S. J. Segal, A. L. Southam and K. D. Schafer. Excerpta Med. Fdn, New York. 